\title{
CHARACTERISTICS OF SOYMILK ADDED WITH DRAGON FRUIT AND EGGPLANT PEEL EXTRACTS
}

\author{
[Karakteristik Susu Kedelai dengan Penambahan Ekstrak Kulit Buah Naga dan Kulit Terong] \\ Diana Sari Kusuma, Filiana Santoso and Elisabeth Kartika Prabawati* \\ Department of Food Technology, Faculty of Life Sciences, Swiss German University, \\ Edu Town BSD City, Tangerang 15339, Indonesia
}

Accepted April 29 2013 / Approved July $16^{\text {th }} 2013$

\begin{abstract}
Soymilk has become progressively consumed in Indonesia since early 1990. However, soymilk has a short shelf life due to its high protein content that promotes growth of spoilage microorganisms. This study was aimed at utilizing peel waste of eggplant (Solanum melongena L.) and dragon fruit (Hylocereus polyrhizus), to prolong shelf life of fresh soymilk through microbial growth inhibition, so that it will not be easily contaminated during storage, transportation and distribution time to meet the needs of consumers. Microbiological analysis showed a notably higher inhibitory effect of dragon fruit peel extract when soymilk was stored at $4^{\circ} \mathrm{C}$ and it exhibited lower number of colonies even after 6 days. Interestingly, the antimicrobial activity of eggplant peel extract in cold soymilk could only be observed on day 3 until day 9 . Hence, it is assumed that chlorogenic acid, as a primary antimicrobial agent in eggplant peel, needed certain time interval to activate its inhibitory activity against microorganism. However, the two peel extracts could not prolong the shelf life of soymilk stored at ambient temperature. All soymilk samples added with the peel extracts fulfilled the Indonesian National standards (SNI) for $\mathrm{pH}$ value, protein, and total solid content. Based on the sensory evaluation, the samples with dragon fruit peel extract attained a comparable acceptance level as plain soymilk and were favored over those added with eggplant extract. In conclusion, this research indicated potential applications of usual household waste of dragon fruit and eggplant peels as antimicrobial agents for protein-rich beverages.
\end{abstract}

Keywords: antimicrobial activity, dragon fruit peel extract, eggplant peel extract, sensory characteristic, soymilk

\section{ABSTRAK}

Susu kedelai, produk olahan kacang kedelai, semakin diminati di Indonesia sejak awal 1990-an. Namun, susu kedelai memiliki umur simpan yang pendek karena kandungan protein yang tinggi mendukung pertumbuhan mikroba pembusuk. Studi ini difokuskan pada pemanfaatan kulit terong (Solanum melongena L.) dan buah naga (Hylocereus polyrhizus) untuk menghambat pertumbuhan mikroba pada sampel susu kedelai, sehingga susu kedelai tidak mudah terkontaminasi selama penyimpanan, transportasi dan proses distribusi untuk bisa memenuhi kebutuhan konsumen. Analisa mikrobiologi menunjukkan ekstrak buah naga bisa bekerja secara efektif pada sampel yang disimpan pada $4^{\circ} \mathrm{C}$. Jumlah koloni mikroba pada susu kedelai dengan ekstrak kulit buah naga juga lebih rendah meskipun telah 6 hari. Menariknya, aktivitas antimikroba dari ekstrak kulit terong dalam susu kedelai dingin baru dapat diamati pada hari ke 3 sampai 9. Oleh karena itu, diasumsikan bahwa asam klorogenat, zat antimikroba utama dalam kulit terong, memerlukan selang waktu tertentu untuk aktivasi penghambatan mikroorganisme. Akan tetapi kedua ekstrak kulit tidak dapat memperpanjang umur simpan susu kedelai yang disimpan pada suhu yang lebih tinggi. Secara umum, semua sampel susu kedelai dengan penambahan ekstrak kulit memenuhi ketentuan standar SNI dalam nilai pH, kadar protein, dan kadar padatan total. Evaluasi sensori membuktikan susu kedelai dengan ekstrak kulit buah naga lebih disukai daripada dengan ekstrak kulit terong dan mempunyai tingkat penerimaan yang sebanding dengan susu kedelai biasa. Sebagai kesimpulan, penelitian ini menunjukkan potensi aplikasi limbah rumah tangga, yaitu kulit buah naga dan terong sebagai zat antimikroba untuk minuman kaya protein.

Kata kunci: aktivitas antimikrobia, ekstrak kulit buah naga, ekstrak kulit terong, sifat sensory, susu kedelai

\section{INTRODUCTION}

It has been over 7.000 years that soy-based products have been consumed by Chinese Population; thus China is referred to as a place where soybean was first cultivated and developed (El Agroudy, et al. 2011). The most popular soy-based product

Paper Presented at International Conference on "Future of Food Factors", October 3-4, 2012, Jakarta, Indonesia.

*Corresponding Author :

Email : elisabeth.prabawati@sgu.ac.id; Phone : +62 2130450045 ext. 5606; Fax.: +62 2130450001 to be consumed at that time was soymilk. It only needs simple and easy processing techniques for consumption. Soymilk is soy-based beverage obtained from a water-extract of soybean; it is white and creamy in appearance similar to that of dairy milk (Momoh et al. 2011). According to Pan and Tangratanavalee (2003), soymilk is produced after soaking and grinding in water.

Soymilk is generally easy to be processed and served, and it provides several health benefits either for short-term or longterm uses. According to Guo and Ono (2005), soymilk contains high amount of good quality proteins and amino acids; and because of its nutritious value, soymilk gives an important role in diets, primarily in most developing countries. Furthermore, 
regular consumptions of soymilk seem to lower cholesterol level in blood due to high amount of unsaturated fatty acids, omega-3 linolenic and omega-6 linoleic acids. It is good for people with lactose intolerance and bovine milk-allergy as well, because it is free from lactose and casein (Jooyandeh, 2011).

As stated by Osuntogun and Aboaba (2004), soymilk becomes susceptible to microbial attack as a consequence of its high nutritive value if it is inappropriately processed and stored. Soymilk spoilages mostly result from mesophilic aerobic bacteria, coliforms, yeasts, and moulds which produce undesirable changes in milk. This problem affects sales, distribution, and transportation; fresh soymilk should always be cooled to maintain its quality and safety (Osuntogun and Aboaba, 2004).

On the other hand, Momoh et al. (2011) report that preserving and prolonging the shelf life of soymilk for certain period is successfully conducted by addition of sodium benzoate. The application of sodium benzoate in the range of 700-800 ppm preserves soymilk up to 13 days at low temperature. Furthermore, the research also proved that dragon fruit (Hylocereus polyrhizus) and eggplant (Solanum melongena L.) are found as potential antimicrobial agents.

According to Stintzing and Carle (2004), Hylocereus species contains high amount of betalain and flavonoid as naturallyoccurring bioactive compounds. Flavonoid is considered to have wide range of biological activities, such as cell proliferation inhibitor, antibacterial, and antioxidant (Soong and Barlow, 2004; Nurmahani et al. 2012). The recent findings on ethanol, chloroform, and hexane extracts of dragon fruit peel show a potent antimicrobial activity. It had been proven to reduce the growth of S. aureus, E. coli, S. typhimurium, and K. Pneumonia (Nurmahani et al. 2012). In the study carried out by Ridwan (2011), the extract of dragon fruit peel inhibits the growth of $L$. Monocytogenes and Enterobacter sp., in addition to $S$. aureus and $E$. coli. Thus, the dragon fruit peel is considered as a natural source of antimicrobial agent.

Moreover, Ding et al. (2009) state that eggplant as one of indigenous plants of Indonesia contains active phytonutrients like flavonoid, such as nasunin and alkaloid compounds from phenolic group e.g. caffeic and chlorogenic acids. The phenolic extract obtained from eggplant fruit has strong antibacterial activities against $S$. aureus, Saccharomyces cerevisiae, and $E$. coli. Besides its antibacterial activities, it is also reported to have antiviral, anti-mutagenic, and lowering LDL properties (Noda et al. 2000). Another study shows chlorogenic and caffeic acids extracted from red (Asparagopsis taxiformis) and brown algae (Sargaddum vulgare) with ethanol act as potential antimicrobial agent (El Mageid et al. 2009). An experiment applying $20 \mu \mathrm{l}$ extract on a $1 \mathrm{~cm}$ diameter paper disc results in a 10-18 $\mathrm{mm}$ inhibition zone for $E$. coli and around $15 \mathrm{~mm}$ diameter-zone against $S$. aureus.

There is limited publication on application of dragon fruit and eggplant peel extracts in food or beverage products, so that the present study was conducted aiming at investigating the behavior and characteristics of both dragon fruit and eggplant peel extracts. This study presents the microbiological and sensory evaluation of the addition of dragon fruit and eggplant peel extracts on soymilk to prolong its shelf life. Based on the finding obtained, it is suggested to expand the application of the extract studied in other types of food and beverage products.

\section{MATERIALS AND METHODS}

The materials used in this research consisted of soybean (Glycine max), which were purchased from a local market Pasar Pagi, Jakarta; while eggplant (Solanum melongena L.) and dragon fruit (Hylocereus polyrhizus) were from Pasar Modern, Serpong, Indonesia. The peels were freshly obtained from the fruits and then chopped. A commercial food-grade Sodium Benzoate (Indonesia) and Ethanol 96\% (Multi Jaya Kimia, Serpong) were used.

\section{Extraction of dragon fruit peel}

Extraction process of dragon fruit peel was conducted according to the method by Maisuthisakul et al. (2007) and Kunnika and Pranee (2011). In this study, $100 \mathrm{~g}$ of homogenized dragon fruit peel was macerated with ethanol (500 $\mathrm{mL}$ ) at $25^{\circ} \mathrm{C}$ for $4.5 \mathrm{~h}$ and was strictly protected from light exposures and then was filtered through a Whatman filter paper no. 1 (Sartorius, Germany). The clear solution of dragon fruits extract was evaporated using vacuum distillation at $50-55^{\circ} \mathrm{C}$ and approximately $63 \mathrm{cmHg}$ vacuum pressure for about $1 \mathrm{~h}$. The crude extract was then centrifuged (Rotina $38 \mathrm{R}$, Hettich, Germany) at $7.000 \mathrm{rpm}$ for $5 \mathrm{~min}$ at $25^{\circ} \mathrm{C}$ and the supernatant was collected and used for analyses.

\section{Extraction of eggplant peel}

To obtain the extract of eggplant peel the extraction method reported by Luthria and Mukhopadhyay (2006) was slightly modified. Reflux method was applied for $100 \mathrm{~g}$ of homogenized eggplant peel with ethanol $(500 \mathrm{~mL})$, at $100^{\circ} \mathrm{C}$ for $30 \mathrm{~min}$. After filtration of the mixture through Whatman filter papers no. 1 (Sartorius, Germany), a clear solution of eggplant extract was continuously processed through distillation at $80-90^{\circ} \mathrm{C}$ for about $6 \mathrm{~h}$. The crude extract was then centrifuged (Rotina $38 \mathrm{R}$, Hettich, Germany) at $7.000 \mathrm{rpm}$ for $5 \mathrm{~min}$ at $25^{\circ} \mathrm{C}$ and the supernatant was collected and used for analyses.

\section{Soy milk production}

Soybeans were soaked in water overnight. The soaked soybeans were homogenized with a soybean:water ratio of 1:5 using a blender (Philips, Indonesia) until the mixture was sufficiently smooth. The slurry was filtered through a filter cloth. The milk was boiled to remove beany flavour. During cooking, the soymilk was added with sugar (PT. Sweet Indolampung, Indonesia) at $10 \% \mathrm{w} / \mathrm{v}$. The foam formed on the surface was continuously removed.

\section{Variation of preservatives added and storage conditions}

The experimental treatments included dragon fruit or eggplant peel extract at concentration of $2.5,5$, and $7.5 \% \mathrm{v} / \mathrm{v}$ and sodium benzoate $0.05 \% \mathrm{w} / \mathrm{v}$ for a positive control. The soymilk products were then packaged and stored. One batch of processed soymilk was divided into two sets, one part was left at room temperature and another was stored in a refrigerator $\left(4^{\circ} \mathrm{C}\right)$. 
The counting number of mesophilic aerobic bacteria from each sample stored at room temperature was conducted at 0,6 , 12,24 , and $48 \mathrm{~h}$ whereas those stored in a refrigerator were done for 3,6 , and $9 \mathrm{~d}$. All sample assay were conducted in triplicates from three batches of soymilk production.

\section{Enumeration of mesophilic aerobic bacteria}

Determination of microbial numbers in soymilk was conducted using a standardized Total Plate Count (TPC) method. The microbes including yeasts and moulds were grown on agar media (Tangwatcharin, 2009). According to Feldsine et al. (2003), for enumeration of mesophilic aerobic bacteria the Buffer Peptone Water (BPW) (Merck, Germany) solution was prepared at $0.85 \% \mathrm{w} / \mathrm{v}$. Dilutions of soymilk products were made up to $10^{-3}$ and $1 \mathrm{ml}$ of each dilution and was aseptically transferred into sterilized Petri dishes in duplicates. Approximately $15 \mathrm{ml}$ of plate count agar media at $\pm 40 \mathrm{C}$ was poured into each Petri dish and allowed to solidify before incubation at $37^{\circ} \mathrm{C}$ for $2-3 \mathrm{~d}$. The total number of bacteria colonies was counted and was then compared to the control expressed in $\mathrm{CFU} / \mathrm{ml}$.

\section{Sensory analysis}

Sensory analysis of soymilk was conducted to determine the palatability, acceptance and preference level of soymilk in a hedonic test method. Four parameters chosen to be analyzed in the hedonic sensory test were taste, aroma (parameter of aroma in this study was referred to the critical beany-off flavor), appearance, and overall acceptance. Around forty untrained panelists aged between 20 and 40 year old were assigned to participate in the test. The hedonic numbering scales were 1 to 7 (7 for the most preferred and 1 for the least preferred). According to method of sensory analysis explained by Pecore et al. (2006) and Bécue-Bertauta et al. (2008), each sample was numbered with a randomized three-digit numbers. Data collected were evaluated by two-factor without replication ANOVA and t-Test was performed to determine significant differences at $p<0.05$.

\section{RESULTS AND DISCUSSION}

The observation on microbiological growth during storage of soymilk, treated and untreated with the extracts, is depicted in Figure 1. The addition of dragon fruit peel extract did not show effective antimicrobial activity in the soymilk. There were no significant differences in the number of microbial colonies between treated compared to untreated products for storage time longer than $12 \mathrm{~h}$, as microbial number of both soymilk products equally increased.

The addition of dragon fruit peel extracts in soymilk in cold storage was effective enough against several types of microorganisms (Figure 2). It was observed that treated soymilk products had slightly different microbial numbers, but insignificant to that of untreated soymilk. Moreover, both Figure 1 and Figure 2 obviously indicate that sodium benzoate is the more effective inhibitor in preserving soymilk compared to dragon fruit peel extract.
The less effective antimicrobial activity was shown by eggplant peel extract in soymilk left at room temperature and no inhibition effect could be observed (Figure 3). During the storage, the number of microbial colonies grew significantly in both treated and untreated soymilk with no significant different microbial numbers could be recorded.

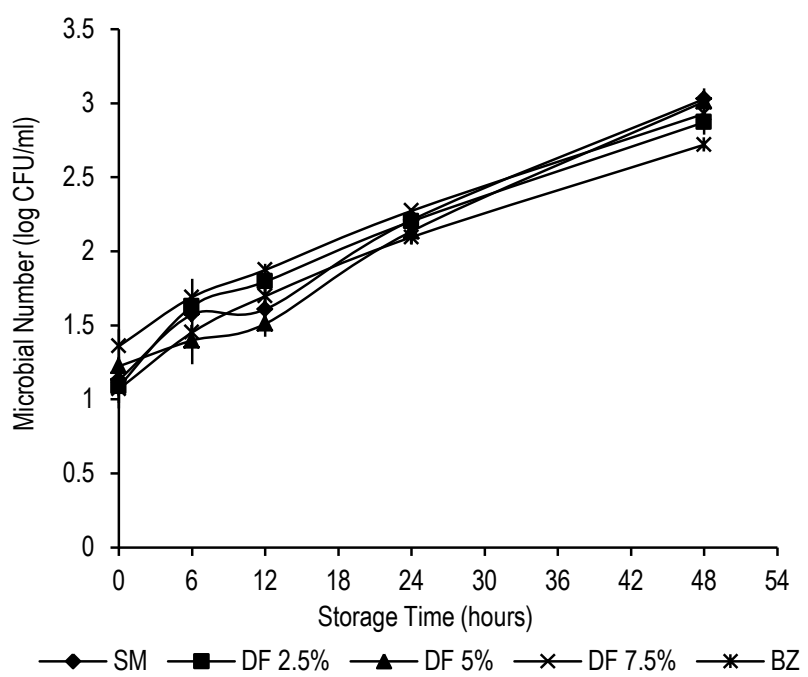

Figure 1. Total Microbial Number of: (1) Untreated Soymilk (SM), (2) Soymilk with $2.5 \%$ of Dragon Fruit Peel Extract (DF 2.5\%), (3) Soymilk with $5 \%$ of Dragon Fruit Peel Extract (DF 5\%), (4) Soymilk with $7.5 \%$ of Dragon Fruit Peel Extract (DF $7.5 \%$ ), and (5) Soymilk with Sodium Benzoate (BZ) at Room Temperature Storage. Values show mean with error bars indicate standard deviation of triplicates experiments $(n=3)$ and determination of significant differences value at $p<0.05$

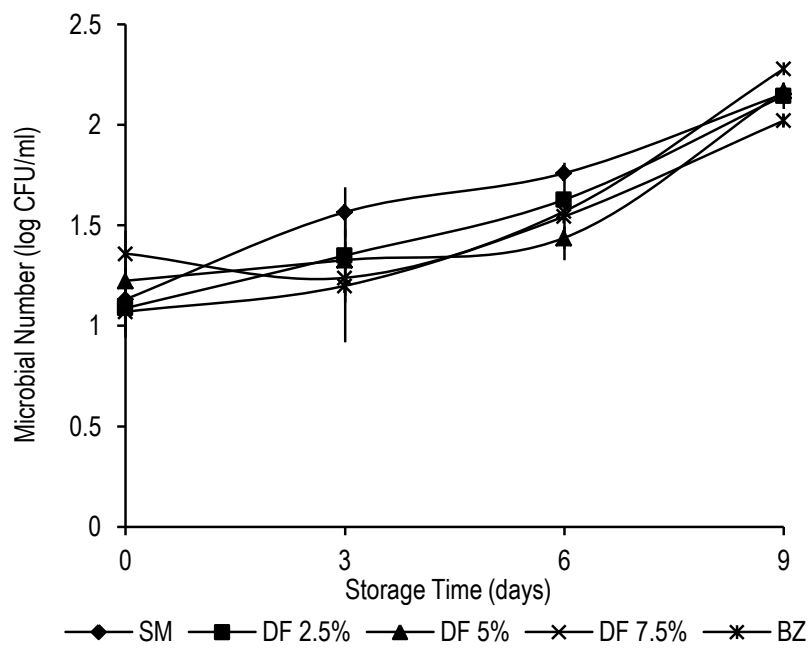

Figure 2. Total Microbial Number of: (1) Untreated Soymilk (SM), (2) Soymilk with $2.5 \%$ of Dragon Fruit Peel Extract (DF 2.5\%), (3) Soymilk with $5 \%$ of Dragon Fruit Peel Extract (DF $5 \%$ ), (4) Soymilk with $7.5 \%$ of Dragon Fruit Peel Extract (DF $7.5 \%$ ), and (5) Soymilk with Sodium Benzoate (BZ) at Refrigerator $\left(4^{\circ} \mathrm{C}\right)$. Values show mean with error bars indicate standard deviation of triplicates experiments $(n=3)$ and determination of significant differences value at $p<0.05$ 
The effective inhibiting effect due to the addition of natural preservatives could only be recorded from soymilk with eggplant peel extract in cold storage as shown in Figure 4. The eggplant peel extract as preservatives, with its antimicrobial agent characteristic, successfully inhibited the growth of microorganisms starting from day 3 of storage even it also kept the number of microbes lower than plain soymilk at significant levels on day 9 . However, sodium benzoate could still exhibit a better preservation against microbial growth compared to eggplant peel extract.

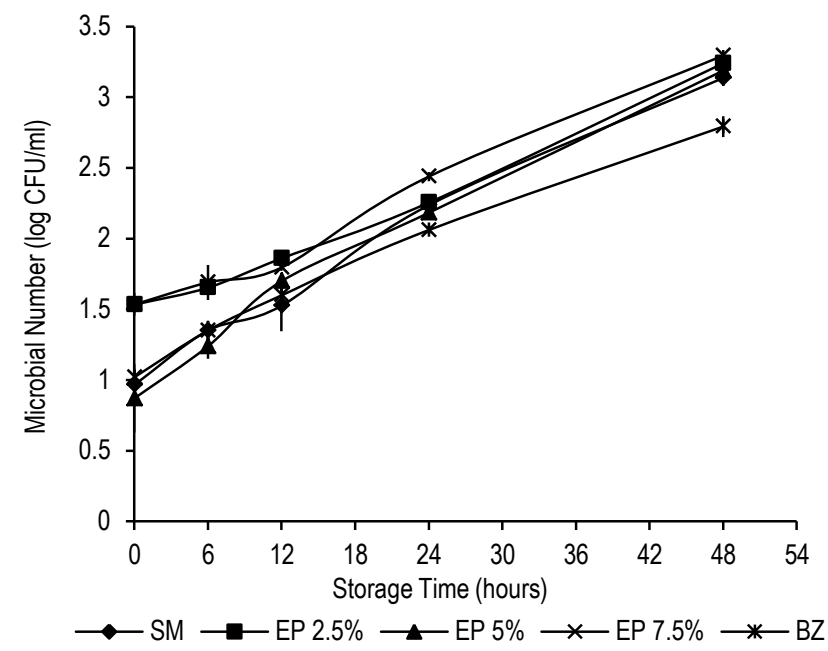

Figure 3. Total Microbial Number of: (1) Untreated Soymilk (SM), (2) Soymilk with $2.5 \%$ of Eggplant Peel Extract (EP 2.5\%), (3) Soymilk with $5 \%$ of Eggplant Peel Extract (EP 5\%), (4) Soymilk with $7.5 \%$ of Eggplant Peel Extract (EP 7.5\%), and (5) Soymilk with Sodium Benzoate (BZ) at Room Temperature Storage. Values show mean with error bars indicate standard deviation of triplicates experiments $(n=3)$ and determination of significant differences value at $p<0.05$

Dragon fruit and eggplant peel extracts, both as preserving agent obtained from natural resources, were previously reported to exhibit antimicrobial activity against several common bacteria strains, yeasts, and molds as reported by Ding et al. (2009) and Nurmahani et al. (2012). The result obtained as depicted in all figures, showed that within the concentration range of $2.5-7.5 \%$ $\mathrm{V} / \mathrm{v}$ the dragon fruit peel extracts added to soymilk had ineffective antimicrobial activity against spoilage microorganisms. As shown in Figure 1, it was obviously illustrated that the total number of microbial counts in all treated products were insignificantly lower compared to that of untreated soymilk as control. Hence, it can be concluded that there was no inhibition effect observed due to the addition of dragon fruit peel extract in soymilk at room temperature.

At different storage conditions, the addition of dragon fruit peel extract to soymilk products and stored in cold storage, still exhibited the same phenomena, as there was no inhibiting effect could be observed from treated products compared to plain soymilk. Referring to the facts that similar total microbial numbers between treated and untreated soymilk, this was possibly because of the low concentration of dragon fruit peel extracts added. Hence, there was insufficient amount of flavonoid bioactive compounds, which are responsible for the antimicrobial activity, to exhibit effective inhibitory effect on total bacterial growth in the products. Consequently, the number of microbial colonies was even higher from day to day during storage compared to that of untreated soymilk.

Similarly, different types of preservatives from eggplant peel extract to soymilk stored at room temperature also obviously illustrated similar trends. At room temperature, the eggplant peel extract could not exhibit effective inhibition against microorganisms, the treated products showed insignificant differences in total enumeration of microorganisms compared to plain soymilk. The reason of this condition was caused by the unstable condition of chlorogenic acid, except at low temperature. In line with the statement of Su et al. (2003), that chlorogenic acid is stable at $4^{\circ} \mathrm{C}$ or below, the effectiveness of chlorogenic acid in eggplant peel as antimicrobial agent was proven in this study (Figure 4).

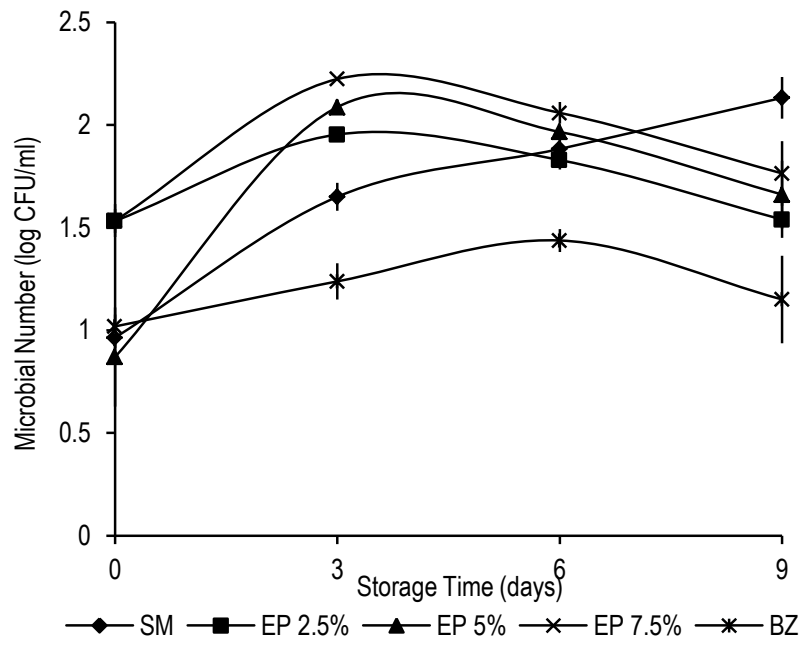

Figure 4. Total Microbial Number of: (1) Untreated Soymilk (SM), (2) Soymilk with $2.5 \%$ of Eggplant Peel Extract (EP 2.5\%), (3) Soymilk with $5 \%$ of Eggplant Peel Extract (EP 5\%), (4) Soymilk with $7.5 \%$ of Eggplant Peel Extract (EP 7.5\%), and (5) Soymilk with Sodium Benzoate (BZ) at $4^{\circ} \mathrm{C}$. Values show mean with error bars indicate standard deviation of triplicates experiments $(n=3)$ and determination of significant differences value at $p<0.05$

Based on the graph in Figure 4, the obvious effectiveness of antimicrobial agent is exhibited after the $3^{\text {rd }}$ day of storage time. At day 3, untreated soymilk had significantly lower number of microbial colonies than the treated soymilk. However, afterward it was found that the microbes in untreated soymilk grew further, whereas, surprisingly the microbial growth in soymilk with eggplant peel extract were significantly inhibited, even it resulted in lower number of microbial colonies until day 9 . This suggests that eggplant peel extract performed effective inhibition effect on microbes as bacteriostatic antimicrobial agent, which could effectively retard the proliferation of new microorganisms in soymilk samples during cold storage after activation

Based on data in Figure 4, it can be concluded that concentration of eggplant peel extracts had positive correlation with the inhibitory effect. The higher concentration of extracts exhibited better antimicrobial activity. Nevertheless, the highest 
concentration of eggplant peel extract $(7.5 \% \mathrm{v} / \mathrm{v})$ could not inhibit the microbial growth as good as sodium benzoate. Thus, sodium benzoate as a synthetic preservative is still better at inhibiting microbial growth compared to natural one, either from dragon fruit or eggplant peels.

Meanwhile, panelists obviously judged that the addition of dragon fruit and eggplant peel extracts in soymilk gave impacts to the level of acceptance by panelists even though at different scores. Overall, dragon fruit peel extract added to soymilk exhibited higher acceptance level to that of untreated soymilk in taste, aroma and appearance levels. In contrast, the soymilk with eggplant peel extract had lower acceptance levels for the tree parameters compared to both untreated soymilk and soymilk with dragon fruit peel extract addition.

Table 1. Scoring result of 7-scale hedonic test sensory analysis

\begin{tabular}{lcccc}
\hline Samples & Taste & Aroma & Appearance & $\begin{array}{c}\text { Overall } \\
\text { Acceptance }\end{array}$ \\
\hline SM & $5.750^{\mathrm{a}}$ & $5.425^{\mathrm{ab}}$ & $5.600^{\mathrm{a}}$ & $5.675^{\mathrm{a}}$ \\
DF 2.5\% & $5.650^{\mathrm{a}}$ & $5.475^{\mathrm{a}}$ & $5.625^{\mathrm{a}}$ & $5.550^{\mathrm{a}}$ \\
DF 5\% & $5.025^{\mathrm{b}}$ & $5.100^{\mathrm{bc}}$ & $4.750^{\mathrm{b}}$ & $4.950^{\mathrm{bc}}$ \\
DF 7.5\% & $4.325^{\mathrm{c}}$ & $4.750^{\mathrm{d}}$ & $4.750^{\mathrm{b}}$ & $4.525^{\mathrm{c}}$ \\
EP 2.5\% & $5.275^{\mathrm{b}}$ & $5.125^{\mathrm{ab}}$ & $4.750^{\mathrm{b}}$ & $5.075^{\mathrm{b}}$ \\
EP 5\% & $3.857^{\mathrm{c}}$ & $4.675^{\mathrm{d}}$ & $3.875^{\mathrm{c}}$ & $4.075^{\mathrm{d}}$ \\
EP 7.5\% & $4.025^{\mathrm{c}}$ & $4.425^{\mathrm{d}}$ & $3.775^{\mathrm{c}}$ & $3.875^{\mathrm{d}}$ \\
BZ & $5.275^{\mathrm{b}}$ & $4.825^{\mathrm{cd}}$ & $5.875^{\mathrm{a}}$ & $5.375^{\mathrm{ab}}$ \\
\hline SM $=$ plain soymilk & & &
\end{tabular}

SM $=$ plain soymilk

DF $2.5 \%=$ soymilk with $2.5 \%$ v/v of dragon fruit peel extract

DF $5 \%=$ soymilk with $5 \%$ v/v of dragon fruit peel extract

DF $7.5 \%=$ soymilk with $7.5 \% \mathrm{v} / \mathrm{v}$ of dragon fruit peel extract

EP $2.5 \%=$ soymilk with $2.5 \% \mathrm{v} / \mathrm{v}$ of eggplant peel extract

EP $5 \%=$ soymilk with $5 \% \mathrm{v} / \mathrm{v}$ of eggplant peel extract

EP $7.5 \%=$ soymilk with $7.5 \%$ v/v of eggplant peel extract

$\mathrm{BZ}=$ soymilk with $0.05 \%$ sodium benzoate

*Value represent means of within the same column, followed by the same letter is not significantly different at $p$-value $<0.05$

\section{CONCLUSION}

Within two different conditions of storage, eggplant peel extract was the one that could successfully exhibit antimicrobial activity against micro-organisms in prolonging shelf life of soymilk at low temperature up to 9 days. It extended the shelf life of soymilk 2 days longer than plain soymilk. In conjunction with the fact, lower temperature, which is not the optimum temperature for microorganisms to grow, is also one important factor to suppress microbial growth, by directly decreased the growth rate, enzyme activities, alteration of cell composition and different nutritional requirements. On the other hand, the addition of $7.5 \%$ dragon fruit peel extract had no effect on extending soymilk shelf-life, thus requiring higher concentration. However, its consumer preferences were more favorable compared to that of eggplant peel extract.

\section{ACKNOWLEDGEMENT}

The authors would like to thank the assistance of the staffs of department of Food Technology, Faculty of Life Sciences, Swiss German University, Indonesia.

\section{REFERENCES}

Bécue-Bertauta M, Álvarez-Esteban R, Pagès J. 2008. Rating of products through scores and free-text assertion: comparing and combining both. Food Qual Prefer 19: 122-134. DOl: 10.1016/ifoodqual.2007.07.006.

Ding YW, Zhou BL, Li ZW, Li ZA, Lin SS. 2009. Study on antimicrobial activities of alkaloid extract from eggplant fruits. Food Sci 30: 95-98.

El Agroudy N, Zaghlol EA, Mokhtar S, Gebaly ME. 2011. An economic study of the production of soybean in egypt. Agric Biol J N Am 2: 221-225.

El Mageid MMA, Salama NA, Saleh MAM, Abo THM. 2009. Antioxidant and Antimicrobial Characteristics of Red and Brown Algae Extracts. 4th Conf Rec Technol Agr.

Feldsine PT, Stephanie CL, Andrew HL, Linda AM, David ET. 2003. Enumeration of total aerobic microorganisms in foods by SimPlate $\AA$ total plate count-color indicator methods and conventional culture methods:collaborative study. J AOAC Int 86: 257-274.

Guo ST, Ono T. 2005. The role of composition and content of protein particles in soymilk on tofu curding by Glucono- $\delta$ lactone or calcium sulfate. J Food Sci 70: C258-C262. DOI: 10.1111/j.1365-2621.2005.tb07170.x.

Jooyandeh H. 2011. Soy products as healthy and functional foods. J Sci Res Middle-East 7: 71-80.

Kunnika S, Pranee A. 2011. Influence of enzyme treatment on bioactive compounds and colour stability of betacyanin in flesh and peel of red dragon fruit Hylocereus polyrhizus (Weber) britton and rose. Int Food Res J 18: 1437-1448.

Luthria DL, Mukhopadhyay S. 2006. Influence of sample preparation on assay of phenolic acids from eggplant. J Agric Food Chem 54: 41-47. DOI: 10.1021/jf0522457.

Maisuthisakul P, Suttajit M, Pongsawatmanit R. 2007. Assessment of phenolics content and free radicalscavenging capacity of some Thai indigenous plants. Food Chem 100: 1409-1418. DOI: 10.1016/f.foodchem.2005. 11.032.

Momoh JE, Udobi CE, Orukotan AA. 2011. Improving the microbial keeping quality of home made soymilk using a combination of preservatives, pasteurization and refrigeration. J Dairy Sci 2: 1-4.

Noda Y, Kaneyuki T, Igarashi K, Mori A, Packer L. 2000. Antioxidant activity of nasunin, an anthocyanin in eggplant peels. Toxicology 148: 119-123. DOl: 10.1016/S0300483X(00)00202-X. 
Nurmahani MM, Osman A, Abdul Hamid A, Mohamad Ghazali F, Pak Dek MS. 2012. Short communication antibacterial property of Hylocereus polyrhizus and Hylocereus undatus peel extracts. Int Food Res J 19: 77-84.

Osuntogun B, Aboaba OO. 2004. Microbiological and physicochemical evaluation of some nonalcoholic beverages. Pak J Nut 3: 188-192. DOI: 10.3923/pin.2004.188.192.

Pan Z, Tangratanavalee W. 2003. Characteristics of soybeans as affected by soaking conditions. LWT-Food Sci Technol 36: 143-151. DOI: 10.1016/S0023-6438(02)00202-5.

Pecore S, Stoer N, Hooge S, Holschuh N, Hulting F, Case F. 2006. Degree of difference testing: a new approach incorporating control lot variability. Food Qual Prefer 17: 552-555. DOl: 10.1016/i.foodqual.2006.01.015.

Ridwan ARS. 2011. Effects of Different Yellow Rock Sugar and Lemon (Citrus limon) Concentrations on Sensory and
Physicochemical Properties of Red Dragon Fruits (Hylocereus polyrhizus) Enzymatic Drink. [Bachelor's thesis]. Tangerang (ID): Universitas Pelita Harapan.

Su YL, Leung LK, Huang Y, Chen Z. 2003. Stability of tea theaflavins and cathechins. Food Chem 83: 189-195. DOl: 10.1016/S0308-8146(03)00062-1.

Soong Y, Barlow PJ. 2004. Antioxidant activity and phenolic content of selected fruit seeds. Food Chem 88: 411-417. DOl: 10.1016/i.foodchem.2004.02.003.

Stintzing FC, Carle R. 2004. Functional properties of anthocyanins and betalains in plants, food and in human nutrition. Trends Food Sci Tech 15: 19-38. DOI: 10.1016/itifs.2003.07.004.

Tangwatcharin R, Sunee L, Fareeda H, Waraporn P. 2009. Research of total plate count, coliforms, and Escherichia coli in drinking water. As J Food Ag-Ind 2: 144-149. 